\title{
PENGARUH MODEL PROBLEM BASED LEARNING BERBASIS LINGKUNGAN TERHADAP HASIL BELAJAR SISWA KELAS X AP PADA MATA AJAR SANITASI, HYGIENE DAN KESELAMATAN KERJA DI SMK PARIWISATA TRIATMA JAYA SINGARAJA TAHUN AJARAN 2018/2019
}

\author{
Yulianitias, Cokorda Istri Raka Marsiti, Luh Masdarini \\ Jurusan Pendidikan Kesejahteraan Keluarga, Fakultas Teknik dan Kejuruan \\ Universitas Pendidikan Ganesha \\ Singaraja, Indonesia \\ E-mail: Yulia.tias@yahoo.co.id, raka.marsiti@undiksha.ac.id \\ masdarini@gmail.com
}

\begin{abstract}
ABSTRAK
Tujuan dari penelitian ini adalah untuk mengetahui perbedaan dari penggunaan model Problem Based Learning berbasis lingkungan terhadap hasil belajar siswa kelas X-AP mata ajar Sanitasi, Hygiene dan Keselamatan kerja di SMK Pariwisata Triatma Jaya Singaraja Tahun Ajaran 2018/2019. Desain penelitian yang digunakan adalah Non equivalent Only Control Group Design. Objek dalam penelitian ini terdiri dari dua kelas sampel, yaitu kelas eksperimen dan kelas kontrol. Metode pemilihan sampel penelitian adalah dengan teknik random sampling. Proses pengumpulan data menggunakan instrumen tes untuk mengetahui hasil belajar siswa, kemudian melakukan pengujian hipotesis dengan menggunakan teknik uji-t. Berdasarkan hasil analisis data, diperoleh $t_{\text {hitung }} 7,641$ dan $t_{\text {tabel }}$ (pada taraf signifikansi $\left.5 \%\right)=3,460$. Hal ini berarti bahwa $t_{\text {hitung }}>t_{\text {tabel }}$, sehingga dapat diinterpretasikan bahwa terdapat pengaruh yang signifikan terhadap hasil belajar siswa X AP Di SMK Pariwisata Triatma Jaya Singaraja antara kelompok siswa yang dibelajarkan dengan Problem Based Learning berbasis lingkungan lebih tinggi dibandingkan kelompok siswa yang dibelajarkan dengan metode konvensional. Dilihat dari hasil perhitungan rata-rata hasil belajar Sanitasi, Hygiene dan Keselamatan kerja kelompok eksperimen adalah 81 lebih besar dari rata-rata hasil belajar Sanitasi, Hygiene dan Keselamatan kerja kelompok kontrol yaitu 76
\end{abstract}

Kata kunci: Hasil belajar Sanitasi, Hygiene dan Keselamatan Kerja, Model Problem Based Learning (PBL) Berbasis Lingkungan

\begin{abstract}
The study aimed at finding out the difference of implementation of problem based learning model with environmental basis towards the achievement of class XAP students on the subjects of sanitation, hygiene, and workplace safety at SMK Pariwisata Triatma Jaya Singaraja on the academic year 2018/2019. The research was designed with non equivalent only group control. The objects were two classes of samples, namely controlled and sample classes. Random sampling method was apllied to determine the sample of the research. The data were gathered by using test to find out the achievement of the students, then examining the hypothesis was done by implementing t-examiner technique. The results show that $t_{\text {value }}$ is 7,641 and $t_{\text {table }}$ (at level of significance $5 \%$ ) $=$ 3,460 . It means that $t_{\text {value }}>t_{\text {table. }}$. It can be interpreted that there is a significant effect towards the students'ahievement of class X AP at SMK Pariwisata Triatma Jaya Singaraja. The group of students that were treated with Problem Based Learning with the environmental basis got the mean score 81 for sanitation, hygiene, and workplace safety, it is higher than those who were treated with conventional method (controlled group).
\end{abstract}

Key words : achievement, sanitation, hygiene, and workplace safety Model 
Problem Based Learning (PBL) with environmental basis

\section{PENDAHULUAN}

Pendidikan adalah suatu proses belajar mengajar yang berlangsung secara efektif dan efisien, secara terbuka dan bertanggung jawab yang disampaikan melalui kegiatan formal dan nonformal antara guru dan siswa. Tujuan dari pendidikan nasional ialah untuk meningkatkan kehidupan bangsa dan mengembangkan manusia seutuhnya. Pendidikan diharapkan dapat meningkatkan kemampuan, mutu kehidupan, serta dapat menghasilkan manusia terdidik. Untuk menghasilkan manusia terdidik ialah dengan cara proses belajar. Belajar adalah suatu proses perubahan tingkah laku individu melalui interaksi dengan lingkungan sekitar. Lingkungan sekitar merupakan sumber bahan belajar yang paling efektif untuk mengajak siswa terlibat, menemukan, dan memecahkan masalah. Menurut Arsyad (2012:34) mengemukakan bahwa belajar adalah suatu proses kompleks yang terjadi pada diri setiap orang sepanjang hidupnya. Proses belajar itu terjadi karena adanya interaksi antara seseorang dengan lingkungannya. Oleh karena itu, belajar dapat terjadi kapan saja dan dimana saja

Sekolah Menengah Kejuruan (SMK) merupakan lanjutan pendidikan menengah pertama yang mempunyai tujuan utama menyiapkan tenaga kerja yang terampil, profesional, dan berdisiplin tinggi sesuai dengan tuntutan dunia kerja. SMK Pariwisata Triatma Jaya Singaraja merupakan sekolah menengah kejuruan pariwisata yang ada di Kabupaten Buleleng Singaraja. Sekolah ini membuka dua keahlian program yaitu jasa boga dan akomodasi perhotelan. Saat ini SMK Pariwisita Triatma Jaya menggunakan kurikulum yaitu kurikulum revisi 2013. Salah satu mata pelajaran yang menggunakan kurikum revisi 2013 ialah mata pelajaran Hygiene dan Sanitasi, mata pelajaran ini muncul didua semester yaitu semester ganjil dan genap

Berdasarkan hasil observasi awal yang dilakukan pada tanggal 23 Desember 2017. Hasil belajar Sanitasi, Hygiene dan Keselamatan Kerja dapat dilihat dari rata-rata UAS yang dicapai siswa kelas $X$ AP Hygiene dan Sanitasi dalam tiap tahun. Persentase ketuntasan nilai UAS dapat dilihat pada Tabel 1.

Tabel 1. Persentase ketuntasan hasil belajar semester ganjil dan genap siswa kelas X AP di SMK Pariwisata Triatma Jaya Tahuun 2015/2016 dan 2016/2017

\begin{tabular}{llr} 
Tahun & Tuntas & Tidak Tuntas \\
\hline $2015 / 2016$ & $60,83 \%$ & $39,16 \%$ \\
\hline $2016 / 2017$ & $71.00 \%$ & $29,00 \%$
\end{tabular}

(Sumber : Daftar niali UAS semester ganjil dan genap guru Hygiene dan Sanitasi kelas $X$ Akomodasi Perhotelan SMK Pariwisata Triatma Jaya Singaraja)

Dari tabel di atas dapat dilihat bahwa persentase nilai hasil belajar siswa pada mata pelajaran Hygiene dan Sanitasi mengalami peningkatan yaitu $10 \%$, hal ini terjadi karena guru mengubah model pembelajaran yang digunakannya. Sebelumnya guru menggunakan metode ceramah pada saat pembelajaran berlangsung namun metode pembelajaran ini membuat siswa menjadi pasif dan kurang aktif di kelas siswa hanya duduk diam dan mendengarkan apa yang guru sampaikan sehingga siswa kurang memahami materi pembelajaran. Kemudian guru mengubah metode pembelajaran menggunakan metode diskusi, dengan menggunakan metode diskusi pada saat proses belajar siswa merasa tertarik dan aktif dalam kelas. Siswa tidak hanya mendengarkan guru namun siswa dapat bertukar pikiran bersama teman diskusinya, hal 
inilah yang membuat siswa lebih memahami materi pembelajaran dan hasil belajar siswa mengalami peningkatan dari sebelumnya. Namun peningkatan hasil belajar siswa masih belum juga mencapai nilai KKM walaupun guru sudah mengubah metode pembelajaran dari ceramah ke diskusi. Adapun KKM yang diterapkan di sekolah tersebut yaitu 75, ini menandakan bahwa hasil belajar Sanitasi, Hygiene dan Keselamatan Kerja siswa kelas $\mathrm{X}$ masih belum optimal. Sesuai dengan uraian tersebut maka guru harus mampu merancang pembelajaran agar dapat menarik bagi siswa salah satunya dengan menerapkan model pembelajaran yang sesuai dengan karakteristik siswa. Salah satu alternative model pembelajaran yang mampu melibatkan siswa secara langsung dan aktif ialah model pembelajaran Problem based Learning. Menurut Hosman (2014:295) bahwa "Problem Based Learning merupakan model pembelajaran dengan pendekatan pembelajaran siswa pada masalah yang nyata sehingga siswa dapat menyusun pengetahuannya sendiri, menumbuh kembangkan keterampilan yang lebih tinggi dan inquiry, memandirikan siswa dan meningkatkan kepercayaan diri sendiri. Pembelajaran dengan model Problem Based Learning diharapkan memberi kesempatan kepada siswa untuk meningkatkan keterampilan kerja ilmiahnya.

Adapun beberapa tahapan dalam model Problem Based Learning antara lain: 1) Orientasi siswa terhadap masalah: a) Membentuk suatu kelompok kerja dan diskusi, b) Menanyakan tujuan, informasi, dan penjelasan dari guru, c) Memotivasi diri dan mempersiapkan segala sesuatu yang dibutuhkan dalam kegiatan belajar.

Pengorganisasian siswa untuk belajar: a) Memahami prosedur dari kegiatan yang akan dilaksanakan,

b)
Merumuskan masalah.

Penyelidikan secara individu maupun kelompok: a) Mengumpulkan data dan informasi yang diperlukan, b) Melakukan kegiatan baik secara individu maupun kelompok. (4) Pengembangan dan penyajian hasil: a) Menganalisis data hasil dan melakukan diskusi. 5) Analisis dan evaluasi prosespemecahan masalah: a) Merefleksi serta mengevaluasi hasil pengamatan dan merumuskan konsep dan kesimpulan

Mata ajar Sanitasi, Hygiene dan Keselamatan Kerja juga cocok untuk model pembelajaran Problem Based Learning berbasis lingkungan dikarenakan kurikulum revisi 2013 dimana siswa lebih ditekankan daripada guru dalam model pembelajaran Problem Based Learning pembelajaran lebih ditekankan kepada siswa, siswa di ajarkan untuk lebih berpikir kritis dan keterampilan memecahakan masalah dan sesuai juga dengan karakteristik mata ajar Hygiene, saniatasi dan Keselamatan Kerja sehingga dalam proses pembelajaran guru memberikan masalah kepada siswa misalnya bagaimana keadaaan sanitasi dan hygiene yang ada di sekolah kita, apa dampak bagi kita jika sanitasi dan hygiene di sekolah tidak bersih dan sehat. Dari pemberian masalah tersebut guru kemudian membagikan siswa kebeberapa kelompok kemudian menyuruh siswa untuk terjun langsung ke lingkungan sekolah seperti toilet dan taman dengan begitu siswa langsung dapat mengetahui secara langsung dan dapat memecahkan masalah yang diberikan oleh guru sehingga proses pembelajaran lebih efektif dan menyenangkan. Dibandingkan dengan model pembelajaran yang di ajarkan oleh guru dengan cara ceramah maupun diskusi, siswa merasa bosan dan kurang memahami materi yang diajarkan selain itu juga media yang digunakan dalam proses 
pembelajaran kurang menarik sehinnga siswa merasa bosan dan malas untuk belajar. Adapun perlakuan yang akan di berikan kepada kelas yang akan mengunakan model Problem Based Learning berbasis lingkungan dengan metode konvensioanal

Model pembelajaran Problem Based Learning akan tercapai dengan optimal, jika dalam penelitian ini dipadukan dengan media pembelajaran yang menarik Media pembelajaran merupakan salah satu komponen komunikasi yang sangat penting dalam menyampaikan suatu materi yang disampaikan komikator (guru) pada komunikasi (siswa) untuk dapat memberikan rangsangan. Dengan menerapkan Problem based Learning berbasis lingkungan sebagai media pembelajaran peserta didik akan lebih tertarik dalam proses pembelajaran karena siswa terpacu oleh rasa keinginan tahunya tentang sesuatu yang ada di lingkungan. Lingkungan sebagai sasaran belajar, sumber belajar dan sarana belajar. Dengan menerapkan model Problem Based Learning berbasis lingkungan siswa belajar tentang cara berpikir kritis, keterampilan memecahkan masalah, dan memperoleh pengetahuan serta konsep esensial dari mata pelajaran dan proses pembelajaran lebih menarik karena siswa terlibat secara langsung dan terjun di lingkungan sehingga.

Bertitik tolak dari latar belakang diatas, maka rumusan masalah dalam penelitian ini adalah pengaruh model pembelajaran Problem Based Learning berbasis lingkungan terhadap hasil belajar siswa kelas $X$ AP pada mata pelajaran Sanitasi, Hygiene dan Keselamatan Kerja di SMK Pariwisata Triatma Jaya?

Berdasarkan rumusan masalah yang telah diuraikan di atas, maka penelitian ini hanya dibatasi mengenai Pengaruh Model Problem
Based Learning berbasis lingkungan Terhadap Hasil Belajar Siswa kelas X AP pada Mata Pelajaran Sanitasi, Hygiene dan Keselamatan Kerja di SMK Pariwisata Triatma Jaya

Sesuai dengan permasalahan yang dijabarkan pada rumusan masalah diatas, adapun tujuan dari diadakan penelitian ini adalah untuk melihat Untuk mengetahui pengaruh model pembelajaran Problem Based Learning berbasis lingkungan terhadap hasil belajar siswa kelas $X$ AP pada mata pelajaran Sanitasi, Hygiene dan Keselamatan Kerja di SMK Pariwisata Tritma Jaya

\section{MODEL PEMBELAJARAN PROBLEM BASED LEARNING}

Menurut Hosnan 2014:295), "Model pembelajaran Problem Based Learning merupakan model pembelajaran dengan pendekatan pembelajaran siswa pada masalah yang nyata sehingga siswa dapat menyusun pengetahuannya sendiri, menumbuh kembangkan keterampilan yang yang lebih tinggi dan inquiry, memandirikan siswa dan meningkatkan kepercayaan diri sendiri".

\section{LINGKUNGAN}

Winamo, (2012: 45). menyatakan, "Lingkungan adalah segala sesuatu yang ada disekitar manusia dan mempengaruhi perkembangan kehidupan manusia. Lingkungan terdiri dari dua komponen abiotik dan biotik. Lingkungan belajar merupakan salah satu bagian dalam pross belajar untuk mencapai tujuan belajar, dimana lingkungan tersebut akan mempengaruhi kegiatan belajar mengajar di sekolah".

\section{HASIL BELAJAR}

Dimyati dan Mudjiono (2013:3), menyatakan " hasil belajar merupakan hasil dari suatu interaksi tindak belajar dan tindak mengajar. 
Dari sisi guru, tindak mengajar diakhiri dengan proses evaluasi hasil belajar"

\section{METODE PENELITIAN}

\section{RANCANGAN PENELITIAN}

Penelitian ini adalah penelitian eksperimen. Penelitian ini bersifat Quasi Eksperimental (Eksperimen Semu), karena peneliti tidak mungkin melakukan kontrol terhadap semua variabel selain perlakukan. Rancangan dalam penelitian ini yakni Non equivalent Posttest Only Control Group Design

\section{Tabel 2}

Desain penelitian "Non equivalent Post Test Only Control Group Design" (Sumber: dimodifikasi dari sugiyono, 2015:502)

\begin{tabular}{rcc} 
Kelompok & Perlakuan & Post- test \\
\hline Eksperimen & $\mathrm{X}$ & $\mathrm{O}_{1}$ \\
\hline Kontrol & - & $\mathrm{O}_{2}$
\end{tabular}

\section{POPULASI DAN SAMPEL PENELITIAN}

Populasi dalam penelitian ini adalah seluruh siswa kelas $X$ AP tahun ajaran 2017/2018 yang berjumlah 154 siswa. Menurut Mardalis, (2008:55), "Sampel berarti contoh, yaitu sebagian dari seluruh individu yang menjadi objek penelitian". Untuk sampel pada penelitian ini adalah siswa kelas X AP 1 yang berjumlah 31 siswa sebagai kelompok kontrol dan siswa kelas $\mathrm{X}$ AP 2 yang berjumlah 31 siswa sebagai kelompok eksperimen yang didapatkan berdasarkan teknik random sampling.

\section{INSTRUMEN DAN TEKNIK ANALISIS INSTRUMEN}

"Metode pengumpulan data merupakan cara atau teknik yang dilakukan untuk mengumpulkan data penelitian" (Arikunto, 2005:101). Instrumen penelitian yang digunakan dalam penelitian ini adalah tes objektif dalam bentuk pilihan ganda. Tes objektif ini terlebih dahulu dilakukan uji instrumen. Uji instrumen tes ini diuji validitas isi oleh 2 orang ahli. Setelah itu, instrumen tersebut diujicobakan pada 32 orang responden yang bukan berasal dari kelompok kontrol maupun kelompok eksperimen. Kemudian, instrumen yang telah diujicobakan kepada responden tersebut, selanjutnya dilakukan pengujian kesahihan instrumen tes yang terdiri atas validitas dan reliabilitas. Rumus yang digunakan untuk uji validitas butir soal dengan point biserial sebagai berikut.

$$
r p b i=\frac{M p-M t}{S t} \sqrt{\frac{p}{q}}
$$

Keterangan:

$$
\begin{aligned}
\mathrm{r}_{\mathrm{pbi}} & =\text { Koefisien korelasi biserial } \\
\mathrm{Mp} & =\text { Rerata skor dari subjek yang } \\
& \text { menjawab betul bagi yang } \\
& \text { dicari butir validasinya } \\
\mathrm{Mt} & =\text { Rerata skor total } \\
\mathrm{St} & =\text { Standar deviasi dari skor } \\
& \text { total } \\
p \quad & =\text { Proporsi peserta didik yang } \\
& \text { menjawab benar } \\
q & =\text { Proporsi peserta didik yang } \\
& \text { menjawab salah }
\end{aligned}
$$

\section{TEKNIK ANALISIS DATA}

Sugiyono (2013:147) mengatakan, "Dalam penelitian kuantitatif, analisis data merupakan kegiatan setelah data dari seluruh responden atau sumber data lain terkumpul. Kegiatan dalam analisis data adalah: mengelompokkan data berdasarkan variabel dan jenis responden, mentabulasi data berdasarkan variabel dari seluruh responden, menyajikan data tiap variabel yang diteliti, melakukan perhitungan untuk 
menjawab rumusan masalah, dan melakukan perhitungan untuk menguji hipotesis yang telah diajukan". Teknik analisis data yang digunakan dalam penelitian ini adalah teknik analisis data uji prasyarat dan uji hipotesis menggunakan independent sample $t$ test. Uji prasyarat yang dilakukan dalam penelitian ini bertujuan untuk membuktikan bahwa data yang dikumpulkan berdistribusi normal dan data berasal dari varian yang homogen. Uji hipotesis menggunakan uji t. Uji hipotesis dilakukan dengan tujuan untuk mengetahui pengaruh penerapan model Problem Based Learning

\section{HASIL PENELITIAN DAN PEMBAHASAN \\ Hasil Penelitian}

Jenis penelitian yang digunakan dalam penelitian ini adalah quasi eksperimen dengan desaian Non equivalent Only Control Group Design yang dianalisis menggunakan uji-t objek yang diteliti adalah hasil belajar siswa mengenai sanitasi, hygiene dan keselamatan kerja kelas $\mathrm{X}$ AP dari penggunaan model Problem Based Learning berbasis Lingkungan dan pembelajaran konvensional

Dalam penelitian ini peneliti memperoleh data dari hasil post-test yang dilakukan di kelas eksperimen dan kelas kontrol. Deskripsi data dalam hasil penelitian ini dikerjakan menggunakan spss 23 . Berikut adalah sajian data dari masing-masing kelompok tersebut.

\begin{tabular}{lll} 
Keterangan & Eksprimen & Kontrol \\
\hline Mean & 81 & 76 \\
\hline Median & 82 & 79 \\
\hline Modus & 85 & 77 \\
\hline $\begin{array}{l}\text { Standar } \\
\text { deviasi }\end{array}$ & 6,232 & 5,000 \\
\hline Varians & 38.838 & 24.995 \\
\hline Minimum & 70 & 65
\end{tabular}

Tabel 3

\section{Hasil belajar kelas eksperimen dan Kontrol}

Pengujian asumsi yang dilakukan meliputi uji normalitas dan sebaran data uji homogenitas varian hasil post test kelompok eksperimen dan kelompok kontrol. Untuk proses uji normalitas data dan uji homogenitas varian menggunakan program SPSS $P C$ 23. Untuk proses pengujian normalitas data menggunakan uji Kolmogorov-Smirnov. Aturan uji normalitas data adalah jika nilai signifikansinya lebih besar dari taraf signifikansi $(\alpha=0,05)$, maka data populasi kelas tersebut dikatakan normal. Hasil pengujian normalitas data pada tabel 4 .

Tabel 4. Uji Normalitas Data

Tests of Normality

\begin{tabular}{|c|c|c|c|}
\hline & \multicolumn{3}{|c|}{ Kolmogorov-Smirnov ${ }^{a}$} \\
\hline & Statistic & Df & Sig. \\
\hline \multicolumn{4}{|l|}{ eksperime } \\
\hline \multicolumn{4}{|l|}{$\mathrm{n}$} \\
\hline \multirow[t]{2}{*}{ Control } & & 3 & \\
\hline & .175 & 0 & .020 \\
\hline
\end{tabular}

a. Lilliefors Significance Correction

Uji homogenitas varian untuk kedua kelompok di gunakan uji $\mathrm{F}$ dengan menggunakan rumus sebagai berikut: found.

Error! Reference source not

$$
\begin{aligned}
& F=\frac{38.838}{24.995} \\
& F=1,55
\end{aligned}
$$

Jadi besarnya $F_{\text {hitung }}=1,55$. Nilai ini kemudian dibandingkan dengan nilai $F_{\text {tabel }} 4.01$ dengan taraf signifikan ditetapkan 0.05 (5\%) maka diperoleh $F_{\text {tabel }}=4.01$. Dalam hal ini berlaku ketentuan, bila nilai 
$\left(\mathrm{F}_{\text {hitung }}<\mathrm{F}_{\text {tabel }}\right)$ maka $\mathrm{H}_{0}$ diterima dan $\mathrm{H}_{\mathrm{a}}$ ditolak. $\mathrm{H}_{0}$ diterima berarti varians homogen.

Berdasarkan hasil pengujian normalitas dan homogenitas, maka diperoleh bahwa data yang didapatkan dari kelompok eksperimen dan kelompok kontrol berdistribusi normal dan homogen. Oleh karena itu untuk uji hipotesis dilakukan dengan menggunakan Uji t Pengujian analisis dilakukan dengan bantuan program SPSS 23. Hipotesis yang diajukan adalah terdapat pengaruh terhadap hasil belajar siswa yang diajarkan dengan menggunakan model Problem Based Learning berbasis lingkungan

Tabel 5. Independent Test

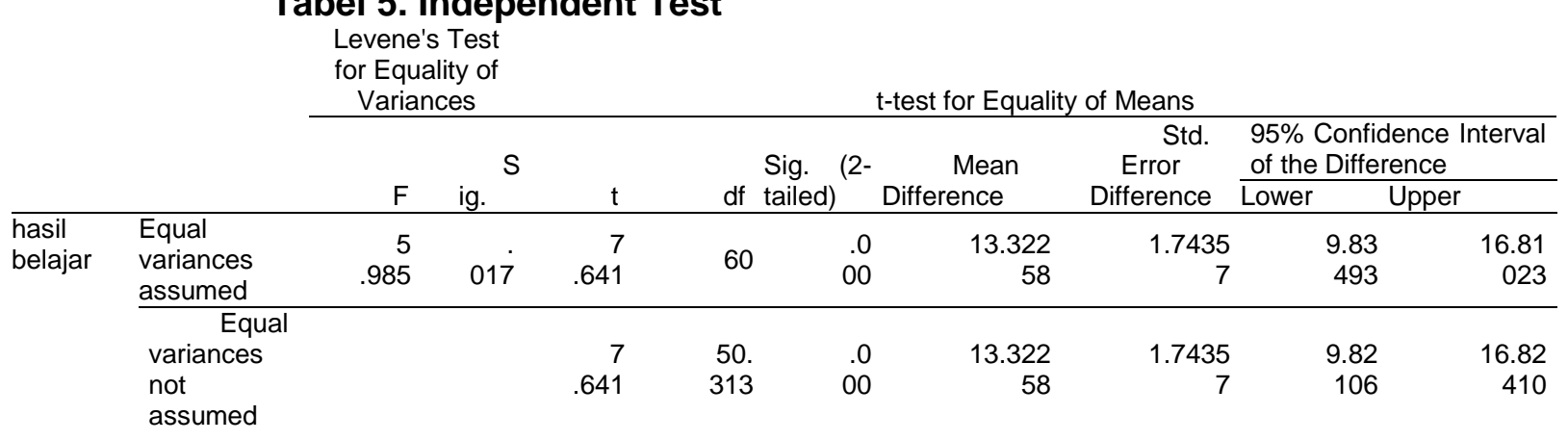

Berdasarkan dari hasil ringkasan tabel diatas, Apabila ditetapkan taraf signifikansi $(\alpha=$ $0,05)$, maka nilai signifikansi $(0,00)$ lebih kecil dari pada nilai taraf signifikansi yang telah ditentukan. Kriteria pengambilan keputusan adalah apabila nilai signifikansi lebih besar dari pada taraf signifikansi $(\alpha=0,05)$, maka $\mathrm{H}_{0}$ diterima dan $\mathrm{H}_{1}$ ditolak. Dan apabila nilai signifikansi lebih kecil dari pada taraf signifikansi $(\alpha=0,05)$, maka $\mathrm{H}_{0}$ ditolak dan

Pada bagian pembahasan ini dibahas mengenai hasil penelitian yang telah diperoleh. Hasil penelitian ini meliputi analisis deskriptif dan analisis statistik yang mengungkap pengaruh variabel bebas terhadap variabel terikat. Variabel bebas dalam penelitian ini adalah Model Problem Based Learning berbasis lingkungan variabel terikatnya adalah hasil belajar siswa Sanitasi, Hygiene dan Keselamatan Kerja. Sebelum ditentukannya anggota sampel untuk penelitian ini, terlebih dahulu ditentukan anggota populasinya. Anggota populasi dalam penelitian ini adalah siswa kelas X AP di SMK Pariwisata Triatma Jaya Singaraja tahun ajaran 2018/2019 yang terdiri dari lima kelas. Kemudian dilakukan penentuan sampel untuk penelitian dalam penentuan sampel tersebut dilakukan secara
$\mathrm{H}_{1}$ diterima. Dalam hasil uji hipotesis menggunakan SPSS 23 didapat 0,000<0,05. Hasil ini menunjukan bahwa $\mathrm{H}_{0}$ ditolak. Jadi terbukti bahwa Terdapat perbedaan hasil belajar. siswa yang menggunakan model pembelajaran Problem Based Learning berbasis lingkungan terhadap hasil belajar Sanitasi, Hygiene dan Keselamatan Kerja dan siswa yang belajar menggunakan model pembelajaran konvensional acak (Random Sampling) dari hal tersebut didapatkan dua kelas untuk dijadikan sampel dalam penelitian yaitu kelas $X \quad A P \quad 1$ berjumlah 31 siswa dan kelas $X$ AP 2 berjumlah 32 siswa. Kelas X-AP 2 sebagai kelas eksperimen dan kelas $X$-AP 1 sebagai kelas kontrol. Setelah dipilinnya kelas X-AP 2 sebagai kelas eksperimen dengan menerapkan model Problem Based Learning berbasis lingkungan dan kelas X-AP 1 sebagai kelas kontrol dengan tetap menggunakan metode konvensional, maka selanjutnya akan dilakukan pengimplementasian dari model pada kelas yang sudah ditentukan. Pengimplementasian model dilakukan selama 4 pertemuan sesuai dengan materi pembelajaran dan KD yang telah disusun sebelumnya. Selanjutnya, setelah pertemuan berakhir maka akan diberikan tes 
akhir berupa pemberian soal posttest dengan soal yang sama untuk kedua kelas baik kelas kontrol maupun eksperimen sebanyak 29 buah soal

Berdasarkan hasil penelitian terdapat perbedaan hasil belajar Sanitasi, Hygiene dan Keselamatan Kerja siswa yang dibelajarkan menggunakan model Problem Based Learning berbasis lingkungan dengan siswa yang dibelajarkan menggunakan metode diskusi disebabkan karena perbedaan perlakuan yang terdapat pada langkah-langkah pembelajaran dan proses penyampaian materi. Pembelajaran pada kelompok eksperimen dengan menggunakan model Problem Based Learning berbasis lingkungan berlangsung secara interaktif, tercipta komunikasi baik antara siswa dengan siswa, maupun siswa dengan guru. Dengan belajar menggunakan model Problem Based Learning berbasis lingkungan, siswa akan secara langsung mengetahui bagaimana pelajaran sanitasi, hygiene dan Keselamatan Kerja yang sedang mereka pelajari. Dengan menggunakan model Problem Based Learning mampu mengembangkan motivasi belajar siswa, mendorong siswa untuk mampu berpikir tingkat tinggi mendorong siswa mengoptimalkan kemampuan metakognisinya dan menjadikan pembelajaran bermakna sehingga mendorong siswa memiliki rasa percaya diri yang tinggi dan mampu belajar secara mandiri. Selain menggunakan model Problem Based Learning pembelajaran juga dibantu oleh media yaitu lingkungan, dimana Mereka tidak hanya sekedar membayangkan, akan tetapi mereka sudah dapat langsung ke lingkungan untuk mengetahui apa itu sanitasi, hygiene dan keselamatan kerja. Pemanfaatan lingkungan sekitar sebagai media belajar dapat menggantikan proses pendidikan konvensional (ruangan) yang selama ini dilakukan secara pasif. Banyak keuntungan yang didapatkan oleh guru dan siswa dengan pemanfaatan lingkungan di dalam proses pembelajaran. Lingkungan sekitar seperti Taman sekolah, Toilet umum di sekolah dan kantin hal tersebut berusaha menciptakan suasana belajar mengajar yang menyenangkan, komunikasi guru dan siswa juga bisa lebih akrab. Aktivitas belajar siswa pun akan lebih intensif siswa tidak hanya berkutat pada materi-materi yang bersifat teoritis akan tetapi mereka menyaksikan secara langsung. Misalnya materi pembelajaran hygiene dan sanitasi mengenai cara mencuci tangan yang baik di washtaffel lingkungan sekolah, siswa tidak hanya diberikan teori-teori mengenai hal tersebut tetapi siswa langsung terjun ke lingkungan untuk mempelajari dengan begitu siswa langsung terlibat dan memiliki pengalam sendiri. Belajar dengan pelibatan lingkungan sekitar juga menciptakan proses pembelajaran yang lebih aktif dan menyenangkan. Sedangkan pada kelompok kontrol, mereka diberikan perlakuan sesuai metode guru pengampu mata pelajaran Sanitasi, hygiene dan keselamatan kerja. Proses belajar mengajar sesuai tahapan guru tersebut, yaitu dengan membuat kelompok kecil kemudian mereka mendiskusikan masalah. Setiap materi yang diberikan, dibuat suatu masalah dan mereka mendiskusikannya. Mereka tidak mendapatkan gambaran secara langsung tentang materi yang sedang mereka pelajari dan mereka tidak diberi contoh langsung tentang materi pembelajaran. Hal ini terkadang sering membuat mereka menjadi bingung pada awalnya dan banyak melakukan kesalahan pada saat melakukan presentasi. Mereka tidak memiliki gambaran secara nyata dan terkadang suasana belajar menjadi tegang karena mereka takut untuk membuat kesalahan. Sehingga, pengetahuan yang mereka peroleh kurang maksimal dan menyebabkan perbedaan hasil yang diperoleh antara kelompok kontrol dan kelompok eksperimen.

Untuk analisis nilai tes akhir (posttest) hasil belajar Sanitasi, Hygiene dan Keselamatan kerja siswa kelompok eksperimen dan kelompok kontrol memiliki perbedaan yang signifikan. Nilai post-test hasil belajar Sanitasi, Hygiene dan Keselamatan kerja yang didapat oleh siswa kelompok eksperimen memiliki nilai rata-rata lebih tinggi dibandingkan hasil nilai rata-rata siswa kelompok kontrol. Hal ini dikarenakan pengimplementasian dari penerapan model Problem Based Learning berbasis lingkungan pada kelas eksperimen yang dilakukan selama penelitian, sehingga keadaaan ini menunjukkan bahwa hasil belajar Sanitasi, Hygiene dan Keselamatan kerja memperoleh nilai rata-rata yang lebih tinggi dibandingkan 
dengan siswa kelompok kontrol yang menggunakan model konvensional dan tidak mendapatkan perlakuan khusus. Selanjutnya untuk perhitungan uji prasyarat baik itu normalitas, homogenitas, dan uji hipotesis menggunakan SPSS 23

Perhitungan uji hipotesis dengan uji-t menggunakan SPSS 23 dengan taraf signifikansi $5 \%$ maka diperoleh nilai $t_{\text {hitung }}$ lebih tinggi dibandingkan dengan $t_{\text {tabel }}$. Karena $t_{\text {hitung }}>t_{\text {tabel }}$ maka $\mathrm{H}_{0}$ ditolak dan $\mathrm{H}_{\mathrm{a}}$ diterima, sedangkan analisis uji-t dengan SPSS mendapatkan hasil $p$ value yang lebih rendah dibandingkan dengan taraf signifikan $(0,05)$. Jika nilai $p$ value lebih kecil dibandingkan nilai taraf signifikan $(0,05)$ maka $\mathrm{H}_{0}$ ditolak, sebaliknya Ha diterima.

Berdasarkan kajian pustaka dan hasil analisis uji-t, maka dapat ditarik kesimpulan bahwa

\section{SIMPULAN DAN SARAN}

Berdasarkan hasil uji hipotesis dengan menggunakan uji t, didapat bahwa nilai $t_{\text {hitung }}(7,641)>t_{\text {tabel }}(4,00)$ pada taraf signifikansi $5 \%$. Dari hasil tersebut, dapat ditarik keputusan bahwa $\mathrm{H}_{0}$ ditolak dan $\mathrm{H}_{1}$ diterima, yang artinya terdapat pengaruh yang signifikan dari Model Problem Based Learning berbasis lingkungan yang diterapkan. Hal tersebut terbukti dari nilai rata-rata hasil belajar Sanitasi, Hygiene dan Keselamatan kerja kedua kelompok, yaitu kelompok eksperimen $=81$ dan kelompok kontrol $=76$. Jadi, penerapan Model Problem Based Learning berbasis lingkungan berpengaruh terhadap hasil belajar kognitif siswa kelas X-AP mata pelajaran Sanitasi, Hygiene dan Keselamatan Kerja di SMK Pariwisata Triatma Jata Singaraja.

Saran yang dapat disampaikan berdasarkan penelitian yang telah dilakukan adalah sebagai berikut. (1) Bagi Siswa, Dengan diadakannya penelitian ini, diharapkan dapat membantu siswa untuk memahami, menggali wawasan yang dipelajari sehingga lebih mudah untuk dimengerti serta membantu proses interaksi baik antara guru dengan siswa maupun siswa dengan siswa (2) Bagi Guru, Dengan diadakannya penelitian ini, diharapkan guru pembelajaran menggunakan Model Problem Based Learning berbasis Lingkungan memberikan pengaruh yang lebih baik terhadap hasil belajar siswa dibandingkan dengan pembelajaran menggunakan metode konvensional pada mata pelajaran Sanitasi, Hygiene dan Keselamatan kerja . Terdapat perbedaan dalam yaitu kelompok eksperimen yang dibelajarkan menggunakan Problem Based Learning berbasis lingkungan memiliki skor rata-rata hasil belajar yang lebih besar dengan nilai rata-rata 81 dari pada kelompok kontrol yang dibelajarkan menggunakan metode konvesional dengan nilai rata-rata 76. Hal ini menunjukkan siswa yang dibelajarkan dengan model Problem Based Learning berbasis lingkungan lebih tinggi dibandingkan dengan siswa yang dibelajarkan dengan menggunakan metode konvensional

dapat menggunakan Problem Based Learning berbasis lingkungan sebagai salah satu alternatif dalam proses pembelajaran untuk membantu siswa mencapai hasil belajar yang maksimal dengan mengajak siswa belajar dengan cara yang menyenangkan. (3) Bagi Sekolah, Dengan diadakannya penelitian ini, diharapkan model Problem Based Learning berbasis lingkungan dapat digunakan sebagai salah satu model belajar yang sesuai dengan karakteristik pembelajaran Sanitasi, Hygiene dan Keselamatan kerja, sehingga mampu meningkatkan pemahaman tentang mata Sanitasi, Hygiene dan Keselamatan kerja. (4) Bagi Peneliti Lain, Dengan diadakannya penelitian ini, diharapkan dapat digunakan sebagai suatu acuan bagi peneliti lain untuk mengembangkan kemampuan dalam mempersiapkan diri sebagai calon pendidik dan meningkatkan pemahaman mengenai pembelajaran menggunakan model Problem Based Learning berbasis lingkungan

\section{DAFTAR PUSTAKA}

Arsyad, 2012. Media Pembelajaran. Jakarta: raja Grafindo Persada

Arikunto, Suharsimi. 2005. "Manajemen Penelitian". Jakarta: Rineka Cipta.

Dimyati dan Mudjiono. 2014. Belajar dan Pembelajaran. Jakarta: Rineka Cipta Kosasih, E. 2014. Strategi Belajar dan 
Jurnal Bosaparis: Pendidikan Kesejahteraan Keluarga

Volume 10, Nomor 2, Juli 2019

Pembelajaran Implementasi

Kurikulum 2013. Bandung: Yrama

Widya.

Hosnan, M. 2014. Pendekatan Saintifik dan

Kontekstual dalam Pembelajaran

Abad 21. Bogor: Ghalia Indonesia.

Koyan,I Wayan.2012. Statistik : Pendidikan

Teknik Analisis Data Kuantitatif.

Singaraja : Universitas Pendidikan

Ganesha.

Mardalis. 2008. Metode Penelitian Suatu

Pendekatan Proposal. Jakarta: Bumi

Aksara

Sugiyono. 2013. "Metode Penelitian

Kuantitatif, Kualitatif, dan R\&D".

Bandung: Alfabeta.

Winamo. 2004. Pengantar Teknologi

Pangan. Jakarta: Gramedia Pustaka 